\title{
The Problems of Turkish Students Studying at Universities of Kyrgyzstan*
}

\begin{abstract}
$\operatorname{Asim}$ ARI $^{* *}$
Received: 21 January 2015

Accepted: 02 June 2015

ABSTRACT: This study aims to determine problems encountered by Turkish students studying at universities of Kyrgyzstan. This is a qualitative, single case study. Participants were 20 students studying at Kyrgyzstan-Turkey Manas University, who were selected through maximum variation sampling In this study, data were obtained through semi-structured interviews Descriptive analysis was carried out to analyze the data. Data obtained from interviews were coded and analyzed in detail. The significant findings of this study revealed that students mostly encountered problems related to communication and bribery during the first days in Kyrgyzstan Among the main problems related to education, an education system, which is based upon rote learning, insufficient language instruction and course materials at preparatory classes were listed.
\end{abstract}

Keywords: Problems of students, undergraduates, international students, Manas University, Kyrgyzstan.

\section{Extended Abstract}

Problem Statement: There is no university where university students have no problems. In each country, there are some problems related to universities. In Turkey, university students have generally emotional, academic, and financial problems (Erkan, Özbay, Cihangir-Çankay, \& Terzi, 2012). These problems may be more severe for students who go abroad to receive education. Students who go to Kyrgyzstan from Turkey also have some problems. The identification of these problems is thought to be useful in solving or at least minimizing them and in providing better education.

Purpose of Study: The aim of this study is to identify the problems encountered by Turkish students studying at universities of Kyrgyzstan.

Method: This study is a qualitative, single case study. Participants were 20 students studying at Kyrgyzstan-Turkey Manas University, who were selected through maximum variation sampling. In the study, data were obtained by semi-structured interviews. Descriptive analysis was carried out to analyze the data. Data obtained through interviews were coded and analyzed in detail.

${ }^{*}$ This study was presented as a paper at the 22 ${ }^{\text {nd }}$ National Congress of Educational Sciences (September 5-7, 2013 Eskisehir Osmangazi University, Eskisehir).

*** Assoc. Prof. Dr., Eskisehir Osmangazi University, Eskişehir, Turkey, ari@ogu.edu.tr

\section{Citation Information}

Ari, A. (2016). Kırgızistan üniversitelerinde öğrenim gören Türkiye vatandaşı öğrencilerin karşılaştığı sorunlar. Kuramsal Eğitimbilim Dergisi [Journal of Theoretical Educational Science], 9(3), 426-440. 
Results: During the first days, students who came to Kyrgyzstan mostly encountered problems related to communication and bribery. The main problems about education are that an education system, which is based upon rote-learning, inadequate language instruction and course materials in prep classes. The problems encountered outside the university are that Kyrgyz people have a prejudiced attitude toward security of life and that students have to give bribes.

Conclusions and Recommendations: It has been pointed out that students who are going to come to Kyrgyzstan have some different goals except receiving education. So, students who are going to come to Kyrgyzstan should be chosen more carefully. It has also been emphasized that orientation for students should be provided, authorities should be in communication with students, and that students should not be left alone. Since there are many students who are disappointed and return to Turkey, here are some suggestions for those who are still seeking for better life in Kyrgyzstan: They should examine the conditions in detail and come to Kyrgyzstan by taking risks, they should not go out alone in the evenings, they should avoid wrong jobs, bars, pavilions, etc., and they should study hard and do their best to represent Turkey. 


\title{
Kırgızistan Üniversitelerinde Öğrenim Gören Türkiye Vatandaşı Öğrencilerin Karşılaştığı Sorunlar *
}

\begin{abstract}
Asım ARI**
Makale Gönderme Tarihi: 21 Ocak 2015 Makale Kabul Tarihi: 2 Haziran 2015

ÖZ: Araştırmanın amacı, Kırgızistan üniversitelerinde öğrenim gören Türkiye vatandaşı öğrencilerin karşılaştıkları sorunları belirlemektir. Nitel bir araştırma olan bu çalışma, durum çalışmasının tek durum yaklaşımı kullanılarak desenlenmiştir. Araştırmanın çalışma grubunu, Kırgızistan Türkiye Manas Üniversitesinde öğrenim gören öğrencilerden görüşmeyi kabul eden 20 öğrenci oluşturmuştur. Grubun oluşturulmasında amaçlı örnekleme tekniklerinden maksimum çeşitlilik örnekleme tekniği kullanılmıştır. Bu araştırmada veriler, görüşme tekniği kullanılarak elde edilmiştir. Verilerin analizinde betimsel analiz kullanılmıştır. Görüşme formlarından elde edilen veriler kodlanarak ayrıntılı şekilde incelenmiştir. Araştırmadan elde edilen bazı önemli bulgular ise şunlardır: Kırgızistan'a geldikleri ilk günlerde öğrencilerin en fazla iletişim (dil) sorunu yaşadığı ve polislerin sık sık durdurup rüşvet istemeleri problemi ile karşılaştı̆̆ görülmüştür. Eğitimle ilgili temel sorunlar arasında "ezberle ve geç" olarak belirttikleri ezbere dayalı öğretimin gerçekleştirilmesi, hazırlık sınıfında dil eğitiminin yeterli verilememesi, derslerle ilgili yeterli kaynak olmaması sıralanmıştır.
\end{abstract}

Anahtar kelimeler: Öğrenci sorunları, üniversite öğrencileri, yurt dışındaki öğrenciler, Manas Üniversitesi, Kirgizistan.

\section{Giriş}

Küreselleşen dünya düzeninden eğitimin de payını aldığı, eğitimin özelikle de yükseköğretimin uluslararası nitelik kazandığı görülmektedir. Bunun yansıması olarak uluslararası öğrenci hareketliği yaşanmakta, öğrenciler eğitim almak amaciyla yurtdışına gitmektedir. Günümüzde öğrenci hareketliliği hız kazanmış, hatta ülkeler öğrenci çekebilmek için cazip seçenekler sunma yarışına girmişlerdir. Özer (2012)'de bir kampüste uluslararası öğrenci ve öğretim elamanlarının yer almasının, doğrudan doğruya sunulan eğitimin biçimini ve niteliğini etkilediğine, ayrıca kültürler arası diyalogun geliştirilmesine de imkân tanındığına dikkat çekmektedir.

Türkiye'de yurtdışına öğrencilerin gönderilmesi ilk olarak 1830 yılında Avrupa ülkelerine gerçekleşmiş olup (Erdoğan, 2010) günümüzde, öğrenciler dünyanın birçok ülkesine eğitim almak için gitmektedir. Bu öğrenci hareketliliğiyle beraber Türkiye'de yükseköğretim giderek artan biçimde uluslararası olma özelliği göstermektedir (Kasapoğlu-Önder ve Balcı, 2010). İnsanların eğitim için başka ülkeleri tercih etmelerinin nedeni daha iyi bir eğitim alma isteği iken Türkiye'de bu tercihlerinde iki sebebin genellikle etkili olduğu söylenmektedir. İlki, sosyo-ekonomik bakımından varlıklı kabul edilen aileler Türkiye'deki üniversiteye giriş sınavları ya da başka nedenlerden dolayı çocuklarını yurtdışındaki daha iyi üniversitelerde okutmak istemeleridir. İkincisi, Türkiye'deki üniversitelere girme hakkı elde edemeyen, ancak Batı ve Amerika üniversitelerinde okuyacak maddi güce de sahip olmayan öğrencilerin

\footnotetext{
* Bu çalışma, 22. Eğitim Bilimleri Kongresinde (Eskişehir Osmangazi Üniversitesi, Eskişehir, 5-7 Eylül 2013) sunulmuştur.

**Doç. Dr., Eskişehir Osmangazi Üniversitesi, Eskişehir, Türkiye, ari@ogu.edu.tr
} 
üniversite eğitiminin ucuz ve nispeten kolay olduğu ülkelerde eğitim almayı tercih etmeleridir. Türkiye'den öğrencilerin yurt dışında öğrenim görmek için en çok tercih ettiği beş ülke 13045 öğrenci ile ABD, 11279 öğrenci ile Almanya, 4010 öğrenci ile Azerbaycan, 3488 öğrenci ile Bulgaristan, 2683 öğrenci ile İngiltere’dir (Öçal, 2012). Azerbaycan dişında diğer Türk cumhuriyetlerine de çok sayıda öğrenci gitmekte olup araştırmaya konu olan Kırgızistan'da da Türk öğrenciler öğrenim görmektedirler.

Kırgızistan'da yükseköğretim; üniversite, akademi, enstitü ve kolejlerde verilir. Yükseköğretimde eğitim vermenin, “çok aşamalı yükseköğretim” ve "sürekli yükseköğretim” olmak üzere iki yapısı vardır. Kırgızistan'da 1990 yılına kadar 10 yükseköğretim kurumu mevcut ise de günümüzde bu sayı 51'dir (Alimbekov, 2001). Kırgızistan yüksek eğitim kurumlarının devlet standartlarına uyup uymadığı bir komisyon tarafından denetlenir. Standartlara uygunluğu denetleyen bu komisyonun (kurumun); yüksek eğitim kurumlarına ve şubelerine izin verme; mezunların eğitim standartlarına uygun eğitim alıp almadığını kontrol etme; eğitim düzen ve kurallarının bozulup bozulmadığını kontrol etme; eğitim başlamadan bina vb. kontrol etme gibi görevleri vardır (Birimkulov, 1996).

Üniversitelere, tam ortaöğretimi ya da mesleki eğitimi bitirenler devam edebilirler. Üniversitenin dört y1lını tamamlayanlar lisans derecesi ve 5-6 y1lı tamamlayanlar yüksek lisans derecesini hak eder. 5-6 y1l üniversite öğrenimi gören öğrenciler doktoraya devam edebilir (Rysalieva \& Ibraeva, 1999). Eğitim ve öğretimde geçmiş dönemden kalma kimi uygulama ve alışkanlıklar hâlâ devam ettiği görülmektedir (Şişman ve Arı, 2009).

Sovyet zamanında uluslararası bilimsel-teknolojik işbirliği Rus devlet kurumu tarafından düzenlendiğinden, Kırgızistan'ın dünya bilim toplumlarıyla ilişkisi ve bilgi paylaşması sınırlı kalmıştır. Bağımsızlığını kazandıktan sonra -özellikle ilk yıllarındatüm bağlarının kopmasıyla bilgiden mahrum kalmış, gelişmeler takip edilememiş ve teknoloji gelişememiştir. Ekonomik imkânların sınırlı olması, bilimsel eserlere ulaşma zorluğu, hızlı beyin göçü ve daha birçok sebep yükseköğretimin niteliğini düşürmüştür. Bu nedenle, yükseköğretimin niteliğini yükseltmek için çalışılmalara başlanılmış, diğer eğitim kademelerinde olduğu gibi yükseköğretimde de devlet standartları oluşturulmuştur. Eğitimle ilgili kanunlar hazırlanmış, diğer ülkelerle anlaşmalar imzalanmış ve yükseköğretim ve bilim alanında Kırgızistan'ın uluslararası işbirliği sağlanmasına çalışılmıştır (Kurbanova, 1999). Türkiye de Kırgızistan ile çeşitli eğitim anlaşmaları yapmış ve bu ülkede eğitim kurumu açılmasına olanak tanınmıştır. Soğuk savaşın sona ermesiyle Orta Asya ve Kafkaslara yönelen Türkiye diş politika araçlarını genişletmeye başlamış, bu amaçla yurt dışında ve dolayısıyla da Kırgızistan'da Türk okulları açılmıştır (Ergin \& Türk, 2010). Türkiye'nin Kırgızistan'daki yükseköğretim düzeyindeki eğitim kurumları şunlardır (Savaş, 2009):

1. Kırgızistan Türkiye Manas Üniversitesi (2 ülkenin yükseköğretim kurumlarına bağlı)

2. Oş Devlet Üniversitesi İlahiyat Fakültesi (Diyanet İşleri Başkanlığg)

3. Alato Atatürk Üniversitesi (özel)

4. Türk Dünyası İşletme Siyasal Bilgiler Fakültesi (Türk Dünyası Araştırmaları Vakfı) 
Kırgızistan Türkiye Manas Üniversitesinde hem Kırgız hem de Türk öğrenciler öğrenim görmektedirler. Kırgız öğrenciler her yıl üniversitenin yaptığı sınav ile alınırken Türk öğrenciler ise ÖSYM sınav ve tercih sistemiyle bu üniversiteye gönderilmektedir. Öğrenciler fakülte ve yüksekokullarda lisans ve ön lisans düzeyinde öğrenim görmektedirler. Kırgız öğrenciler kazandıkları bölümde öğrenime başlamadan önce Türkçe öğrenimine yönelik bir yıl hazırlık sınıfına gitmektedirler. Aynı şekilde Türk öğrenciler de bir yıl dil hazırlık sınıfında Kırgızca öğrenmektedirler. Üniversitede sonraki yıllarda eğitim Kırgız ve Türk öğretim elamanlarınca Kırgızca ve Türkçe verilmektedir.

Her ülkede üniversiteye başlayan öğrenciler birtakım sorunlarla karşılaşabilirler. Türkiye'de üniversite öğrencilerinin genellikle duygusal, akademik ve ekonomik vb. problemler yaşadığı görülmektedir (Erkan ve diğerleri, 2012). Özellikle başka ülkelere eğitim almak için giden öğrenciler bu sorunlarla daha fazla karşılaşmaktadırlar. Türkiye'den Kırgızistan'a eğitim almak için giden öğrenciler de çeşitli sorunlarla karş1 karşıya gelmektedir. Sorunların en aza indirgenmesinde ve öğrencilerin daha verimli eğitim almalarının sağlanabilmesinde yaşanan sorunların belirlenmesinin yararlı olabileceği düşünülmüştür. Bunun sonucunda da ilgili araştırma desenlenmiştir. Dolayısıyla araştırmanın amacı, Kırgızistan-Türkiye Manas Üniversitesinde öğrenim gören Türkiye vatandaşı öğrencilerin karşılaştıkları sorunları öğrenci görüşlerine göre belirlemektir. Bu amaca ulaşabilmek için aşağıdaki sorulara yanıt aranacaktır.

1. Kırgızistan'da eğitim görmeye ilişkin duygu ve düşünceler nelerdir?

2. Kırgızistan'a gelinen ilk günlerde en sık hangi sorunlarla karşılaşılmıştır?

3. Kırgızistan'da eğitim-öğretim ile ilgili en sık karşılaşılan sorunlar nelerdir?

4. Kırgızistan'da okul dışı yaşantıyla ile ilgili en çok karşılaşılan sorunlar nelerdir?

5. Bu konular dışında karşılaşılan sorunlar nelerdir?

6. Öğrencilerin Kırgızistan'a gelmeden önce Türk yetkililerin neler yapmas1/yapmaması konusunda tavsiyeleri nelerdir?

7. Öğrencilerin Kırgızistan'a gelmeden önce kendilerinin neler yapmas1/yapmaması konusunda tavsiyeleri nelerdir?

8. Öğrencilerin Kırgızistan'da öğrenim gördükleri sürece, Türk yetkililerin öğrenciler için neler yapması/yapmaması konusunda tavsiyeleri nelerdir?

9. Öğrencilerin Kırgızistan'da öğrenim gördükleri sürece, Kırgız yetkililerin öğrenciler için neler yapması/yapmaması konusunda tavsiyeleri nelerdir?

10. Öğrencilerin Kırgızistan’da öğrenim gördükleri sürece, öğrencilerin neler yapması/yapmaması konusunda tavsiyeleri nelerdir? 


\section{Yöntem}

\section{Araştırma deseni}

$\mathrm{Bu}$ çalışmada nitel araştırma desenlerinden olgubilim yaklaşımı kullanılmıştır. Olgubilim deseni, farkında olduğumuz ancak derinlemesine ve ayrıntılı bir anlayışa sahip olmadığımız olgulara odaklanmaktadır. Olgular; yaşadığımız dünyada olaylar, deneyimler, algılar, yönelimler, kavramlar ve durumlar gibi çeşitli biçimlerde karşımıza çıkabilmektedir. Bize tümüyle yabancı olmayan aynı zamanda da tam anlamını kavrayamadığımız olguları araştırmayı amaçlayan çalışmalar için olgubilim uygun bir araştırma zemini oluşturur (Yıldırım \& Şimşek, 2011).

\section{Çalışma grubu}

\section{Tablo 1}

Çalışma Grubu Öğretmenlerin Özellikleri

\begin{tabular}{|c|c|c|c|c|}
\hline No & Cinsiyet & Yaş & Sinıf & Fakülte \\
\hline 1 & $\mathrm{E}$ & 22 & 2 & Ziraat \\
\hline 2 & E & 20 & 1 & Edebiyat \\
\hline 3 & E & 22 & 3 & İktisadi ve İdari Bilimler \\
\hline 4 & $\mathrm{E}$ & 25 & 2 & Edebiyat \\
\hline 5 & $\mathrm{E}$ & 20 & 1 & İletişim \\
\hline 6 & $\mathrm{~K}$ & 22 & 3 & Mühendislik \\
\hline 7 & $\mathrm{E}$ & 20 & $\mathrm{H}$ & İletişim \\
\hline 8 & $\mathrm{E}$ & 19 & $\mathrm{H}$ & İletişim \\
\hline 9 & E & 19 & 1 & Edebiyat \\
\hline 10 & $\mathrm{E}$ & 20 & $\mathrm{H}$ & Edebiyat \\
\hline 11 & E & 24 & $\mathrm{H}$ & Edebiyat \\
\hline 12 & $\mathrm{E}$ & 20 & $\mathrm{H}$ & İktisadi ve İdari Bilimler \\
\hline 13 & $\mathrm{~K}$ & 20 & $\mathrm{H}$ & İktisadi ve İdari Bilimler \\
\hline 14 & $\mathrm{E}$ & 19 & $\mathrm{H}$ & İletişim \\
\hline 15 & $\mathrm{~K}$ & 22 & 3 & İktisadi ve İdari Bilimler \\
\hline 16 & E & 23 & 3 & Mühendislik \\
\hline 17 & E & 18 & $\mathrm{H}$ & İletişim \\
\hline 18 & $\mathrm{~K}$ & 21 & 2 & Edebiyat \\
\hline 19 & $\mathrm{~K}$ & 23 & 3 & Edebiyat \\
\hline 20 & $\mathrm{~K}$ & 19 & $\mathrm{H}$ & İktisadi ve İdari Bilimler \\
\hline
\end{tabular}


Kırgızistan Türkiye Manas Üniversitesinde öğrenim gören öğrencilerden görüşmeyi kabul eden 20 öğrenci araştırmanın çalışma grubunu oluşturmuştur. Grubun oluşturulmasında amaçlı örnekleme tekniklerinden maksimum çeşitlilik örnekleme tekniği kullanılmıştır. Maksimum çeşitlilik örneklemesinde, göreli olarak küçük bir örneklem oluşturmak ve bu örneklemde çalışılan probleme taraf olabilecek bireylerin çeşitliliğini maksimum derecede yansıtmak hedeflenir. Maksimum çeşitliliğe dayalı bir örneklem oluşturulmasında amaç, çeşitlilik gerektiren durumlar arasında herhangi ortak ya da paylaşılan olguların olup olmadığını bulmaya çalışmak ve bu çeşitliliğe göre problemin farklı boyutlarını ortaya koymaktır (Yıldırım \& Şimşek, 2011). Çalışmada öğrencilerin cinsiyet, yaş, sınıf düzeyleri ve fakülte farklılıkları bu çeşitliliğin sağlanmasında dikkate alınacak boyutlar olarak karar verilmiştir. Bu çeşitliliklerin örnekleme mümkün oluğunca yansitılmasına çalışılmıştır. Çalışma grubunu oluşturan öğrencilerin özellikleri aşağıda Tablo 1 'de yer almaktadır.

Çalışma grubu beş fakülteden altı kadın, 14 erkek toplam 20 öğrenciden oluşmaktadır. Üniversitede öğrenim gören öğrencilerin çoğunluğunu erkeklerin oluşturması çalışmaya katılan kadınların sayısını daha az olarak yansıtmıştır. Öğrencilerin yaş dağılımı 18 ile 25 yaş aralığındadır. Çalışma grubunda hazırlık dâhil tüm sinıflardan öğrenci yer almaktadır.

\section{Verilerin toplanmasi}

$\mathrm{Bu}$ çalışmada veriler derinlemesine bilgi alınmasını sağlayan görüşme tekniği kullanılarak elde edilmiştir. Bir amaç için yapılan, soru sorma ve yanıtlama tarzına dayalı karşılıklı ve etkileşimli bir iletişim süreci olan görüşme yoluyla deneyimler, tutumlar, düşünceler, niyetler, yorumlar, zihinsel algılar ve tepkiler gibi gözlemlenemeyenler anlamaya çalışılır (Yıldırım \& Şimşek, 2011). Veri toplama aracı olarak araştırmacı tarafindan yarı yapılandırılmış görüşme formu geliştirilmiştir. Literatür taramasından ve Arı (2007)'nin yapmış olduğu benzer çalışmanın veri toplama aracından yararlanılarak görüşme formunda yer alacak sorular belirlenmiştir. Sorular açık uçlu soru ve yarı yapılandırılmış görüşme formuna uygun şekilde tasarlanmış olup görüşme formunda 10 madde yer almıştır. Veri toplama aracının kapsam geçerliğinin sağlanması için görüşme formlarındaki sorular Kırgızistan Türkiye Manas Üniversitesinde görev yapmış iki öğretim üyesi tarafından incelenmiştir. Uzman görüşlerinden yeterli dönüt sağlandığına kanaat oluştuğundan alınan görüşler dikkate alınarak görüşme formu yeniden düzenlenmiştir.

Görüşmeler Mayıs 2013 tarihinde anketör aracılı̆̆ ile gerçekleştirilmiştir. Görüşmeyi gerçekleştiren Kırgızistan Türkiye Manas Üniversitesinde görev yapmakta olan öğretim elamanına çalışma ve görüşme formunun uygulanması hakkında ayrıntılı bilgi verilmiştir. Maksimum örnekleme tekniğine uygun olarak, anketör ders çıkışlarında öğrencilerin yoğunlukta bulunduğu kantin, yemekhane vb. alanlarda görüşmeleri gerçekleştirmeye çalışmıştır. Anketör, görüşmeden önce öğrencilerle ön görüşmeler yapılmış, çalışmanın amacı, katkıları vb. açıklanmış ve görüşme formu katılımcıya verilerek görüşme öncesinde soruları incelemesine firsat verilmiştir. 
Görüşmeler anketörün, görüşme formunda yer alan soruları öğrencilere sorması ve öğrencilerden gelen yanıtları görüşme formuna not alması şeklinde gerçekleşmiştir. Görüşme sonrasında bu notlar hemen düzenlenmiş, görüşülen kişilerle paylaşılmıştır. Eklemek istedikleri noktalar ile ilgili görüşleri alınmış, ekleme ve düzetmeleri yapılmıştır. Görüşmeler sonucunda elde edilen veriler yapıldığ 1 biçimiyle herhangi bir işlem yapılmaksızın anketör tarafından araştırmacıya gönderilmiştir.

\section{Verilerin analizi}

Betimsel analiz yöntemi kullanılarak çalışmada elde edilen veriler analiz edilmiştir. Elde edilen verilerin daha önceden belirlenen temalara göre özetlendiği ve yorumlandığı betimsel analizde, görüşülen bireylerin görüşlerini çarpıcı bir biçimde yansıtmak amacıyla doğrudan alıntılara yer verilir. Betimsel analizde amaç, elde edilen bulguları düzenlenmiş ve yorumlanmış bir biçimde okuyucuya sunmaktır (Yıldırım ve Şimşek, 2011). Veriler analize hazır hâle getirildikten sonra görüşme formlarından elde edilen bütün veriler kodlanarak ayrıntılı şekilde incelenmiştir. Temaların oluşturulması sürecinde, çalışmanın amacı, görüşme soruları literatür taramasına bağlı olarak hazırlanan araştırmanın kuramsal çerçevesi temel alınmıştır. Her soruya ilişkin katılımcıların verdikleri cevaplar bu temalara göre işlenmiş, listesi çıkarılmış, bulgular tanımlanmış ve yorumlanmıştır. Bulgular kısmında öğrenci isimleri açık olarak verilmemiş, Ö1, Ö2,..Ö13 kodları kullanılmıştır. Analiz sürecinde verilerin temalara dağıtımında başka bir araştırmacının da görüşüne başvurulmuştur. Çalışmalar arası tutarlılık hesaplaması için Miles ve Huberman (1994)'ün önerdiği güvenirlik formülü [Güvenirlik = Görüş Birliği/(Görüş Birliği + Görüş Ayrılığ $)$ ] kullanılmış, hesaplama sonucunda araştırmanın güvenirliğinin \%80'in üzerinde olduğu belirlenmiştir.

Nitel araştırmada geçerlik araştırmacının araştırdığı olguyu, olduğu biçimiyle ve olabildiğince yansız gözlemlenmesi anlamına gelmektedir (Kirk \& Miller, 1986, aktaran Yıldırım \& Şimşek, 2011). Bulgular bölümünde çalışmada elde edilen veriler sunulurken, önce bulguların tamamı yorum yapılmadan doğrudan verilmiş ve duruma ilişkin bilgiler ortaya konulduktan sonra yorumlama yoluna gidilmiştir. Çalışmanın yöntem bölümünde çalışmanın modeli, çalışma grubu, veri toplama aracının oluşturulması, verilerin toplanması ve analizi ile ilgili ayrıntılı açıklamalara yer verilmiştir. Üzerinde çalışılan durum ve kullanılan yöntemler çalışmanın ilgili bölümlerinde detaylarıyla sunulmuş, böylelikle benzer araştırma yapacak araştırmacılara çalışma desenlerini kurgularken yardımcı da olunabilecektir. Araştırmada ulaşılan bulgular başka araştırma sonuçlarıyla karşılaştırılarak dış ölçütler çerçevesinde geçerlik aranmıştır. Böylece analizin geçerliği ve güvenirliği sağlanmaya çalış1mıştır.

\section{Bulgular}

$\mathrm{Bu}$ bölümde, çalışmada öğrencilerin sorulara verdiği cevapların incelenip değerlendirilmesiyle elde edilen bulgular araştırmanın alt amaçları doğrultusunda sınıflandırılarak sunulmuştur. Bununla birlikte öğrencilerin görüşlerinden doğrudan alıntılara yer verilmiştir. 


\section{Kırgızistan'da eğitim görmeye ilişkin duygu ve düşünceler}

Katılımcıların birçoğu (12 katılımcı) Kırgızistan'da eğitim almalarıyla ilgili sistem ve düzey farklılığı gibi nedenlerden dolayı birtakım sıkıntı, zorluk yaşadığını dile getirmiştir. Bunun yanında öğrenciler (7 katılımcı) Kırgızistan'da eğitim görmenin birçok iyi imkân sunduğunu ve eğitim almanın çok güzel bir duygu olduğunu da söylemişledir. Kırgızistan'ın özellikle dil eğitimi konusunda öğrencilere avantajlar ve firsatlar sunduğu vurgulanmıştır (6 katılımc1). Bu konuyla ilgili katılımcılardan doğrudan alıntılara aşağıda yer verilmiştir.

K6: Kırgızistan'da eğitim görmek ile ilgili çok güzel olanaklarımız var. Türkiye'de bulamayacağımız bir çok imkana burada çok kolay ulaşabiliyoruz. Özellikle dil eğitimi konusunda. Tabi ki farklı kültürler tanımakta bizim için gelecekte ve gireceğimiz ortamlarda bize avantaj. Kırgızistan veya başka bir ülke yurt dışında eğitim almak gerçekten büyük bir avantaj.

K11: Eğitim sisteminin tamamen ezbere dayalı oluşu ve de Türk eğitim sistemine tamamen zit oluşu buraya gelen öğrencilerdeki okuma azmini kırmakta...

K14: Kırgızistan'da ki eğitim Türkiye ye kıyasla çok geride...

K16: Kırgızistan'da eğitim görmek gerçekten güzel, çünkü birçok olanak sağlyyor.

\section{Kırgızistan'a gelinen ilk günlerde en sık karşılaşılan sorunlar}

Kırgızistan'a geldikleri ilk günlerde farklı mekân ve kültürle karşılaştıklarından öğrencilerin en fazla buradaki yaşama uyum sorunu yaşadıkları gözlemlenmiştir (11 katılımc1). En çok karşılaşılan bir diğer sorun da dil bilmediklerinden öğrencilerin iletişim kurmada zorluk yaşaması olmuştur (11 katılımc1). Polislerin öğrencilerden rüşvet almasının onları şaşırtan ve rahatsız eden bir durum oluşturduğu dile getirilmiştir (5 katılımc1). Ayrıca resmi evrakların tamamlanmasında birtakım problemler yaşanması (2 katılımc1) ve öğrenciye verilen rehberliğin yetersiz olması karşılaş1lan sorunlar arasında sıralanmıştır (3 katılımcı). Aşağıda bunlarla ilgili olarak katılımcılardan alıntılar yer almıştır.

K2: İlk geldiğimde polislerin bizi durdurup bizden para istemeleri ve bizim dil sorunumuzun olmasıydı. Polislerin bizi sık sık durdurup para istemeleri kendimizi açık hapishanede hissediyormuşuz gibi hissettirdi.

K3: Hayata alışmak, yaşam standartlarının zorluğu ve ailemden ilk kez uzak kalmam.

K5: Kırgızistan'da rehberlik sıkıntısı yaşadık. İnsanlarla anlaşamama, yeme ve içme

K13: Resmi evraklar Türkiye ile irtibata geçmemiz çok zamanımızı alıyor. Evraklarımız gününde ulaşması zor oldu.

K14: Polis sorunu ve rüşvet sorunu. Sürekli önümüzü kesip, durduk yere para isterler. Rahat bir şekilde dışarıda dolaşamıyoruz. Özellikle akşamları çok tehlikeli.

K16: İletişim, dil sorunu, ilgisizlik.

\section{Eğitim-öğretimle ilgili en sık karşılaşılan sorunlar}

Hazırlık sınıfında verilen dil eğitiminin yetersiz olması ve buna bağlı olarak öğrencilerin derslerinde eğitim-öğretim terimlerini anlayamamaları eğitimleriyle ilgili en fazla karşılaştıkları sorun olmuştur (12 katılımcı). Öğrenciler aldıkları eğitim düzeyinin düşüklüğüne ve öğretim elemanlarının yetersizliğine karşılaştıkları sorunlar arasında yer vermişlerdir (6 katılımcı). Ders materyal ve kaynaklarının yeterli olmaması 
karşılaşılan bir diğer sorun olarak görülmüştür (4 katılımc1). Bunlarla ilgili katılımcılardan doğrudan alıntılar aşağıda verilmiştir.

K2: Eğitim sisteminde problem yok ama bazı hocaların eğitimi ve eğitim teknikleri bizi sıkmaktadır ve bunaltıyor dersten...

K5: Eğitim ve öğretimde terimlerin anlaşılmazlığı. Derslerde yeterli kaynakların olmayışı

K6: Eğitim konusunda bariz problemler var, yeteri kadar bilgi alamıyoruz. Sistem, destek ortada adı var kendi yok desek yeri. Öğretim konusu da ortada bazı kişilerin çabası olsa da yeterli düzeyde değil ve yarıda kalıyor.

K10: Dil eğitim aşamasında işlenen metotların faydalı olmadığı halde 1srarla devam etmesi ve idarenin bu duruma cevapsız kalması, tarihi ve milli olaylar, kişiler ile meşgul edilerek alınması gereken eğitimin engellenmesi.

K14: Hala lise, ortaokul zihniyeti var. Üniversiteli olduğumuzu hissedemedik. Ayrıca bir dil (Kırgızca) bence böyle öğretilmez. Bence bu kitapların incelenmesi ve gerçekten dil öğretmek yönünde yenilenmesi lazım.

K20: Dersler çok monoton geçiyor. Hep aynı olduğundan belli saatten sonra dinlemek çok zor oluyor. Bence derslerde daha fazla materyal kullanılması gerekir.

\section{Okul dışı yaşantıyla ile ilgili en çok karşılaşılan sorunlar}

Öğrencilerin günlük yaşamlarında en fazla karşılaştıkları sorunun Türk vatandaşlarına karşı ön yargıyla yaklaşılması ve sosyal yaşamda bunun sıkıntılar oluşturmasıdır (13 katılımc1). Daha önceki yıllarda yaşanan kötü örneklerden dolayı Türk vatandaşlarına karşı Kırgız halkı nezdinde olumsuz bir imaj oluşmuş olmasının öğrencilere ön yargıyla bakılmasına neden olduğuna dikkat çekilmiştir. Günlük yaşamda kendilerini çok kolay bir tartışmanın hatta kavganın içinde bulduklarını ve dolayısıyla güvenlik problemleri yaşadıklarını (10 katılımcı) dile getirmiştir. Polisin öğrencilere karşı tutumu ve öğrencilerden rüşvet alınması okul dışında karşılaşılan sorunlar arasında yer almıştır (4 katılımcı). Ayrıca halk nezdinde Türklerin "para ağacı" ya da "ayaklı dolar" gibi görülmesinden duyulan rahatsızlık da dile getirilmiştir (2 katılımcı). Bu konuyla ilgili katılımcılardan doğrudan alıntılara aşağıda yer verilmiştir.

K2: Bazı Kırgız vatandaşların bizi hor görüp sataşmaları...

K4: Okul dışı yaşantımda yukarda da belirttiğim gibi rüşvet sorunudur. Özellikle yeni gelen öğrenci için bu büyük bir sorun olmaktadır.

K6: ..., sürekli kandırılmak için uğraşlan bir toplumda olmak kötü bir duygu. Yeterince demek bile fazla olan can güvenliğimizin neredeyse olmadığı. Haklarımızın hiçe sayıldığı bir yerdeyiz...

K11: Okul dışındaki yaşantımızda biz Türkler sadece para ağacı gibi görülen, kendi konsolosluğu tarafindan bile korunamayan, aşağılık mahluklar gibi görülen insanlarız. Buradaki insanlar bizim buraya gelişimizin en temel sebebinin seks olduğunu zannetmekte ve kötü yönlü tavır almaktadır.

K17: Her an kendinizi bir kavgada bulabilirsiniz. Tabi buna mecbur değilsiniz ama her şey için küçük bir kıvılcım yetiyor.

\section{Öğrencilerin Kırgızistan'a gelmeden önce Türk yetkililerin yapması/ yapmaması gerekenler}

Öğrencilerin Türk yetkililerinden en fazla talep ettikleri öğrencilere daha ayrıntılı bilgilendirme yapılması, seminer verilmesi olmuştur (10 katılımc1). Evrak işlemlerinde yardımcı olmaları, bu işlemleri kolaylaştırmalarını istemeleri ikinci sırada 
yer almıştır (5 katılımc1). Kırgızistan'a öğrenim görmeye gidecek öğrencilerin seçiminde daha dikkatli olunması, seçme sisteminin gözden geçirilmesi önerilmiştir (3 katılımcı). Ayrıca, öğrencilerin ilk gelişlerinde yurda kadar yetkililerce getirilip yerleştirilmesi (2 katılımc1), elçiliğin tam gün hizmet vermesi (1 katılımc1), vize ve diğer evrak işlemlerinin üniversite tarafından takibinin yapılması (1 katılımcı) da öneriler arasında yer almıştır. Aşağıda bunlarla ilgili olarak katılımcılardan alıntılar yer almıştır.

K1: Buraya gelecek öğrenciler daha ayrıntılı bilgilendirilmeli ve öğretimle ilgili seminer, internet aracılığı ile bilgilendirilmeler yapılmalı.

K2: Her öğrenciyle ilgilenip onları yurda kadar teslim etmeleri gerekir. Dışarda kalmaması lazım. Bu onları dış tehlikelerden korur ve güvence altına alır.

K7: Öncelikle buraya gelen öğrenciler çok iyi seçilmeli. Bu olmuyorsa puanlar yükseltilmeli. Çok düşük puanlara adam geliyor, çok boş ve lakayt insanlar var. Bunlarda hem ülke, hem de Türk milleti adına kötü prestij olarak geri dönüyor.

K13: Türk yetkililerin biraz bize yardımcı olması evrak işleri yönünden ve ülke yönünden de tanıtım yapması gerekir. Çünkü internette Kırgızistan hakkında çok bilgi yok.

K19: Türk yetkililerin öğrencilere seminerler vererek onları bilinçlendirmelerini istiyorum.

\section{Öğrencilerin Kırgızistan'a gelmeden önce yapması/yapmaması gerekenler}

Kırgızistan'a gelecek öğrencilere öncelikle Kırgızistan'da hayat şartları, öğrenim durumu, bölüm özellikleri vb. konularda iyi araştırma yaparak doğru ve güvenilir kaynaklardan bilgi edinmeleri (17 katılımc1), iyice düşünmeleri ve hayal kırıklığına uğramamak için psikolojik olarak kendilerini hazırlamaları (10 katılımcı) önerilmiştir. Ayrıca, öneriler arasında problem yaşamamaları için evraklarını eksiksiz getirmeleri (3 katılımc1), kulaktan duyma sözlere itibar etmemeleri (5 katılımc1), Ziraat Bankasından VISA kart almaları (1 katılımcı) yer almıştır. Bunlarla ilgili katılımcılardan doğrudan alıntılar aşağıda verilmiştir.

K6: Buraya gelecek öğrenci ilk önce neden geldiğini düşünmeli amacını doğru seçmeli üniversite kazandım özgürüm diyerek gelmemeli. Beklentilerini bilmeli ve gerçekten araştırma yaparak gerçekten istediği ve aradığı burada mı bilmeli ve ona göre hareket etmeli.

K8: Kırgızistan'da gelecek öğrencilerin bu ülke hakkında doğru ve güvenilir bilgiler alamsı ve buraya geldiğinde "Ben nereye geldim?" şeklinde şaş̧ınlık bildiren soruları sormaması. Kayıt evraklarını eksiksiz getirmeleri kendileri için daha iyi olur.

K10: Kendilerini bir kültür şokuna, farklı bir coğrafyaya, farklı bir toplumda yaşamaya uygun hale getirmelilerdir. Sonrasında duygusallığ 1 bir kenara atıp bir birey olduğunun bilincine varmak, o olgunluklara göğüs gerecek hazır hale gelmeliler. Ve en önemlisi psikolojik olarak hazırlanmalilar.

K14: Ziraat banktan viza kart almaların kesinlikle tavsiye ederim. Ve gelmeden önce burayı çok iyi araştırmaları lazım. Çünkü her gelen önce hayal kırıklı̆̆ına uğruyor. Ve geri dönen öğrenci sayısı çok fazla.

K20: Öncelikle sadece kulaktan duyma sözlerle buraya gelmeleri onlar için büyük bir hata olur. Çünkü buraya gelenlerin büyük çoğunluğu hayal kırıklığına uğruyor. Buraya gelmeden önce burayı iyice araştırıp şartları göze alarak gelmeleri onlar için daha sağlıklı olur. 


\section{Kırgızistan’da öğrenim gördükleri sürece, Türk yetkililerin öğrenciler için yapması gerekenler}

Öğrenciler Türk yetkililerden kendileriyle iletişimi koparmayarak ilgilenmelerini ve öğrencilere sahip çıkmalarını, kendilerine değer vermelerini istemişlerdir (15 katılımcı). Türk vatandaşlarının Kırgızistan'daki olumsuz imajının düzeltilmesi için çalışılması önerilmiş (4 katılımcı), yetkililerin daha aktif çalışması gerektiğgine vurgu yapılmıştır. Ayrıca öneriler arasında, yurttaki imkânların iyileştirilmesi (4 katılımcı), Türk-Kırgız ayrımının yapılmaması (5 katılımc1), öğrenciye sunulan kütüphane, sağlık ve diğer sosyal imkânların iyileştirilmesi (4 katılımc1), öğrencilerin can güvenliğ i konusunda tedbirler alınması (3 katılımcı), psikolojik danışma merkezinin daha aktif çalışması (1 katılımc1), dil ve staj programının genişletilmesi (1 katılımcı) yer almıştır. $\mathrm{Bu}$ konuyla ilgili katılımcılardan doğrudan alıntılara aşağıda yer verilmiştir.

K4: Türk yetkililerin en az 2 haftada bir öğrencilerle diyalog kurmaları ve onlarla sürekli haberdar olmaları gerekir. Bu en önemli faktör.

K8: Üniversitenin sosyal faaliyetleri Türkiye'deki bir üniversiteyle karşılaştırıldığında çok yetersiz dah geliştirilmeli. Üniversite kütüphanelerinde Türkiye'de çıkan kitapların öğrencilerin hizmetine sunulması. Üniversitenin öğrencilere spor salonu( koşu bandı, bisiklet vs.) gibi aletlerin bulunduğu bir hizmet sunması. Etkinliklerin arzında Kırgız öğrencilere pozitif ayrımcılığın uygulanmaması.

K7: Türk'e sahip çıkılması. Yurttaki sıcak su sorununun giderilmesi. Kırgız-Türk ayrımının yapılmaması. Türkiye'nin gerektiği kadar bu ülkede ağırlığı hissettirmesi. Çünkü milyonlarca dolar harcanıyor. Ama Türkiye'nin ve milletinin bu ülkede değeri olmuyor.

K9: Türk öğrencilere sahip çıkılması. Yurttaki su sorununun çözülmesi. Türkiye'nin gerektiği kadar bu ülkede ağırlığının hissettirilmesi.

K14: Bir kere Türk öğrencilerin her konuda yardıma ihtiyacı var. Burada Türkler bana göre çok önemli değil. Bu okulun amacı Kırgızlar ile Türklerin sözde kaynaşması için açılmış. Ama böyle bir şey yok. Türk yetkilileri burada her zaman Türk öğrencileri koruması lazım. Ama böyle bir şeyde yok.

K19: Öğrencilerin can güvenliğini güvenceye almalarını öneririm...

\section{Kırgızistan’da öğrenim gördükleri sürece, Kırgız yetkililerin öğrenciler için yapması gerekenler}

Kırgız yetkililerden öğrenciler için en çok yapılması istenilen polislerin rüşvet almasının önüne geçilmesi ve öğrenci güvenliğinin daha iyi sağlanması olmuştur (9 katılımc1). Öğrenciler, polisin ve diğer devlet memurlarının Kırgız-Türk ayrımı yapmayarak daha adil davranması gerektiğini ikinci olarak en fazla önermişlerdir (7 katılımcı). Bunların yanında vize ile ilgili işlemlerde kolaylık sağlanması (2 katılımcı), misafir öğrencileri destekleme fonu açılması (1 katılımc1), yetkililerin üniversiteye gelerek öğrencileri bilinçlendirmesi (1 katılımc1) yapılması istenilen öneriler arasında yer almıştır. Aşağıda bunlarla ilgili olarak katılımcılardan alıntılar yer almıştır.

K3: Hepimize aynı yaklaşmalarını, Kırgız ve Türk ayrımı yapmamalarını isterim.

K6: Şu polisin rüşvet alma konusu ortadan kalkmalı kesinlikle ve problem olduğunda dinlenmeden önce kesin Kırgız haklıdır zihniyeti ortadan kalkmalı. Güvenli ortamlar kesinlikle sağlanmalı ve denetimi \%100 arttırılmalı. 
K8: Kırgız yetkilileri Türklere daha yakın, iyimser gözle bakıp, onların güvenliklerini daha iyi bir şekilde sağlamalarını arzu ediyorum. Özellikle Cal kampüsünde büyük bir güvenlik sıkıntısı var. Kampüsün kenarları çevrili olmadığı için gereksiz boş insanlar kampüsün içine rahatça girip yer yer büyük sıkıntılar doğurabiliyorlar.

K13: Polislerin Türklere karşı iyi ve ayrımcıllk yapmamasını ve Türklerin zengin olması gözüyle bakmaması gerekir.

K19: Üniversitelere gelerek öğrencileri bilinçlendirmesini tavsiye ederim.

\section{Kırgızistan’da öğrenim gördükleri sürece, öğrencilerin yapması/yapmaması gerekenler}

Öğrencilerin pek dışarıya çıkmamaları (özellikle geceleri), tartışmadan uzak durmaları, olaylara karışmamaları, gece hayatından uzak durmaları istenmiş (11 katılımc1) ve sadece dersleriyle ve kendilerini ilgilendiren konularla uğraşmaları önerilmiştir (5 katılımc1). Ayrıca, ırk, kültür, din vb. ayrımı yapmaktan kaçınmaları (3 katılımc1), Türkiye'yi ve Türk halkını en iyi şekilde temsil etmeleri (3 katılımc1), okudukları yeri kötülememeleri (1 katılımcı), okula devamsızlık konusunda dikkatli olmaları (1 katılımı), belgeleri ile beraber dışarı çıkmaları (1 katılımcı), rüşvet vermemeleri (1 katılımcı) öneriler arasında yer almıştır. Bunlarla ilgili katılımcılardan doğrudan alıntılar aşağıda verilmiştir.

K2: Pek dışarıya çıkmayıp, başka hayata bağlanmayıp, derslerini çalışmasıdır.

K7: Öncelikle kendilerine saygılarının olmasını. Fakat bu olmuyorsa başka insanlara ırk, kültür yahut din ayrımı yapmadan saygılı olmasını. Yedikleri veya okudukları yeri kötülememeleri. Yani yedikleri kaba pislememeleri. Geleceğini düşünüp plan üretmeleri. Türk milletini iyi temsil etmeleri.

K8: Öğrenciler dil problemlerini çözmeden Türkiye'de olduğu gibi çok rahat olmamalı, geceleri dışarıya çıkmamaları daha iyi olur. Burada bulundukları takdirde (TC. Vatandaşı öğrencilerinin) Türkiye ve Türk halkını çok iyi bir şekilde temsil edilmesi gerekir.

K12: Öğrenciler suçlu olacakları hiçbir şey yapmasınlar. Belgeleriyle beraber dışarı çıksınlar.

K14: Okuldan eve/yurda, yurttan/eve okula gitmelerini tavsiye ederim. Birde devamsızlık konusuna çok dikkat etmeliler.

\section{Sonuçlar}

Çalışmanın bulgularından elde edilen önemli sonuçlar aşağıda sıralanmıştır.

1. Kırgızistan'da eğitim almayla ilgili olarak bazı zorluklar yaşansa da birçok iyi imkânın olduğu ve özellikle dil eğitimi konusunda öğrencilere firsatlar sunulduğu görülmüștür.

2. Yaşama uyum sağlama, iletişim kurma güçlüğü, polislerin rüşvet istemesi öğrencilerin Kırgızistan'a geldikleri ilk günlerde en fazla yaşadıkları sorunlar arasında yer almıştır.

3. Aldıkları eğitimle ilgili olarak hazırlık sınıfında verilen dil eğitiminin yetersiz olması, eğitim düzeyinin düşüklüğü, öğretim elemanlarının yetersizliği, ders materyal ve kaynaklarının yeterli olmaması yaşanan sorunlar arasında sıralanmıştır. 
4. Türk vatandaşlarına karşı ön yargıyla yaklaşılması, güvenlik problemleri, polislerin rüşvet alması öğrencilerin günlük yaşamlarında en fazla karşılaştıkları sorunlar olmuştur.

5. Öğrenciler Kırgızistan'a gelmeden önce Türk yetkililerin öğrencilere daha ayrıntılı bilgilendirme yapmalarını, evrak işlemlerinde yardımcı olmalarını, öğrencilerin seçiminde daha dikkatli olmalarını, ilk gelişlerinde yurda kadar getirmelerini talep etmişlerdir.

6. Kırgızistan'a gelecek öğrencilere Kırgızistan'la ilgili bilgi edinmeleri, iyice düşünmeleri, psikolojik olarak kendilerini hazırlamaları, evraklarını eksiksiz getirmeleri verilen öneriler arasında yer almıştır.

7. Öğrenciler Kırgızistan'da öğrenim gördükleri sürece Türk yetkililerden kendileriyle iletişimi koparmayarak ilgilenmelerini, Türk vatandaşlarının Kırgızistan'daki olumsuz imajının düzeltilmesi için çalışmalarını, yurtkütüphane vb. sosyal imkânları iyileştirmelerini, Türk-Kırgız ayrımının yapılmamasını, can güvenliği konusunda tedbirler almalarını istemişlerdir.

8. Öğrencilerin Kırgız yetkililerden istekleri arasında polislerin rüşvet almasının önüne geçilmesi, güvenliğin daha iyi sağlanması, Kırgı-Türk ayrımı yapmaksızın daha adil davranılması, vize ile ilgili işlemlerde kolaylık sağlanması yer almıştır.

9. Kırgızistan'da öğrenim gördükleri sürece öğrencilere pek dişarıya çıkmamaları (özellikle geceleri), tartışmadan ve gece hayatından uzak durmaları, sadece dersleriyle ilgilenmeleri, ırk-kültür-din vb. ayrımı yapmaktan kaçınmaları, Türkiye'yi en iyi şekilde temsil etmeleri önerilmiştir.

\section{Kaynakça}

Alimbekov, A. (2001) Kırgız Cumhuriyeti ve eğitim sistemi hakkında genel bilgi. Türk Yurdu, 21(171), 13-15.

Arı, A. (2007). Yabancı uyruklu öğrencilerin Türkiye'de aldıkları lisansüstü eğitimin değerlendirilmesi (Kırgızistan örneği). III. Lisansüstü Eğitim Sempozyumu Bildiriler Kitabı (ss. 38-43). Eskişehir: Anadolu Üniversitesi.

Birimkulov, U. (Red.-Ed.-) (1996) Gosudarstvennıy obrazovatelnıy standart viş̧ego obrazovaniya-tom I [Yüksek öğretimin devlet eğitim standard1-cilt I]. Bişkek: Ministerstvo Obrazovaniye İ Nauki Kırgızskoy Respubliki.

Erdoğan, A. (2010). Tanzimat döneminde yurtdışına öğrenci gönderme olgusu ve Osmanlı modernleşmesine etkileri. Sosyoloji Dergisi, 20, 121-151.

Ergin, G., \& Türk, F. (2010). Türkiye'de öğrenim gören Orta Asyalı öğrenciler. Sosyal ve Beşeri Bilimler Dergisi, 2(1), 35-41.

Erkan, S., Özbay, Y., Cihangir-Çankay, Z., \& Terzi, Ş. (2012). Üniversite öğrencilerinin yaşadıkları problemler ve psikolojik yardım arama gönüllükleri. Eğitim ve Bilim, 37(164), 94-107. 
Kasapoğlu-Önder, R., \& Balc1, A.(2010). Erasmus öğrenci öğrenim hareketliliği programının 2007 yılında programdan yararlanan Türk öğrenciler üzerindeki etkileri. Ankara Avrupa Çalışmaları Dergisi, 9(2), 93-116.

Kurbanova, N. U. (1999) Mecdunarodnoe sotrudniçestvo kırglzstana v oblasti visşego obrazovaniya i nauki [Yüksek eğitim ve bilim alanında Kırgızistan'ın uluslararası işbirliği]. Bişkek: Kırgızskaya Agrarnaya Akademiya.

Miles, M. B., \& Huberman, A. M. (1994). Qualitative data analysis: An expanded sourcebook. CA:SAGE Publications.

Öçal, Ş. (2012). Yurt dışı eğitimi: sorunlar ve çözüm önerileri. Eğitime Bakıļ, 23, 36-41.

Özer, M. (2012). Türkiye'de uluslararası öğrenciler. Yükseköğretim ve Bilim Dergisi, 2(1), 10-13.

Rysalieva, S. DJ. \& Ibraeva, G. (1999) Educational financing and budgeting in Kyrgyzstan [Working document]. Paris: UNESCO.

Savaş, S. (2009). Türk Dünyasında eğitim alanındaki gelişmeler ve yenilikler. Journal of Azerbaijani Studies, 10-12, 269-283.

Şişman, M., \& Arı, A. (2009). Kırgızistan'da eğitimin temel problemleri ve öğretmenlerin hizmet içi eğitim ihtiyacı. Kırgızistan Türkiye Manas Üniversitesi Sosyal Bilimler Dergisi, 21, 133-147.

Yıldırım, A., \& Şimşek, H. (2011). Sosyal bilimlerde nitel araştırma yöntemleri. Ankara: Seçkin Yayıncılık. 